\title{
Chapter 1 \\ The Productivity Puzzle: A Critical \\ Assessment and an Outlook \\ on the COVID-19 Crisis
}

\author{
Felix Roth
}

\begin{abstract}
This contribution critically assesses the productivity puzzle and gives an outlook on the COVID-19 crisis. It offers two main conclusions. First, it posits that a large fraction of the productivity puzzle can be solved by incorporating intangible capital into the asset boundary of the national accounts. Thus, the productivity puzzle is largely explained as a consequence of fundamental structural changes that are underway, transforming industrial economies into knowledge economies. Secondly, the contribution foresees a post-COVID-19 scenario that is likely to lead to a pronounced increase in labor productivity growth. This depends, however, on whether the current push for digitization will be backed by actual investments in digitization and the necessary complementary investments in (business and public) intangible capital.
\end{abstract}

Keywords Productivity puzzle - Intangible capital - Labor productivity growth · Structural change $\cdot$ COVID-19 crisis $\cdot$ Remeasurement of GDP

JEL Classifications E22 $\cdot \mathrm{F} 45 \cdot \mathrm{O} 32 \cdot \mathrm{O} 34 \cdot \mathrm{O} 47 \cdot \mathrm{O} 52$

Originally published in: Thomas Straubhaar (ed.). Neuvermessung der Datenökonomie. Hamburg University Press, Hamburg, 2021, pp. 61-82.

This contribution is based on the author's Habilitation colloquium lecture entitled "The Productivity Puzzle: A Critical Assessment", which he delivered before the Habilitation Committee of the faculty of Business, Economics, and Social Sciences at the University of Hamburg on June 29, 2020 (Roth, 2020a). A German translation of the contribution appeared as Chap. 3 of an edited volume published by Hamburg University Press in April 2021 (Roth, 2021).

\footnotetext{
Felix Roth $(\bowtie)$

Department of Economics, University of Hamburg, Hamburg, Germany

e-mail: felix.roth@uni-hamburg.de 


\section{Introduction}

Labor productivity growth is a central contributor to an economy's competitiveness (Krugman, 1994) and rising prosperity (Heil, 2018). In most advanced economies, it is of key importance in maintaining the standard of living in societies experiencing population aging (Posen \& Zettelmeyer, 2019). Despite its importance, it is widely acknowledged that advanced economies, such as the US and the EU, have suffered a pronounced decline in labor productivity growth rates since the start of the Great Recession in 2007 (Oulton, 2018; Van Ark \& O’Mahony, 2016; Van Ark, 2016; Van Ark \& Jäger, 2017; Van Ark et al., 2018). In the aftermath of the financial crisis (2008-15/16), these rates have been more than halved compared to the pre-crisis period (1995-2004/07) (Remes et al., 2018; Brynjolfsson et al., 2019; Van Ark et al., 2018).

Although a steady decline in labor productivity growth can be observed in these economies from the 1970s onward (Gordon, 2018; Bergeaud et al., 2016; Brynjolfsson et al., 2019)_despite the exceptional experience of the US in the mid-to-late 1990s - the magnitude of the decline since the start of the Great Recession (2008-2013/16) has posed a conundrum to many scholars (Oulton, 2018; Remes et al., 2018; Van Ark \& Jäger, 2017)—principally for two reasons.

First, the decline was puzzling given that real interest rates were close to or below zero (Teulings \& Baldwin, 2014; Summers, 2015; Haskel \& Westlake, 2018a). Second, the decline was puzzling as it occurred in the midst of ongoing revolutions in both information and communications technology (ICT) and in artificial intelligence (AI) (OECD, 2015). Economists have attempted to capture this conundrum under several multifaceted labels, such as "the Secular Stagnation Puzzle" (Summers, 2014, 2015; Teulings \& Baldwin, 2014), "the Modern Productivity Paradox" (Brynjolfsson et al., 2019), or simply "the Productivity Puzzle" (Haskel \& Westlake, 2018a). This contribution critically discusses this conundrum by exploring the key role of intangibles in labor productivity growth. It also explores current issues arising from the COVID-19 crisis.

This contribution is organized as follows: it opens by offering some brief introductory remarks and a summary of its main findings and their implications. Second, it sketches an intangible capital-augmented model for labor productivity growth as developed by Roth and Thum in 2013. Third, the contribution reviews salient trends in labor productivity growth from 1950 until 2006. Fourth, it elaborates upon the pronounced decline in productivity experienced from 2007 to 2015 , which first prompted the ongoing discussion among economists over this so-called "productivity puzzle". Fifth, the contribution critically discusses this perplexing "puzzle" by elaborating upon the key role of intangibles in labor productivity growth. Sixth, it explores current issues arising from the COVID-19 crisis. And finally, the contribution offers two main conclusions. 


\section{Determinants of Labor Productivity Growth}

This section elaborates the determinants of labor productivity growth by presenting an intangible capital-augmented model specification. This model was first developed by Roth and Thum in 2013 in the context of a European Commission-funded project entitled Intangible Capital and Innovations: Drivers of Growth and Location in the EU (INNODRIVE) (INNODRIVE, 2011; Roth \& Thum, 2013). It is currently being used in a subsequent project called GLOBALINTO (GLOBALINTO, 2020), which is devoted to capturing the value of intangible assets in microdata to promote the EU's growth and competitiveness (Roth, 2020b). The model specification follows an approach developed by Benhabib and Spiegel in 1994, which is coined "crosscountry growth accounting". The approach differs from the framework of traditional single growth accounting methodology in two ways. First, the output elasticities are estimated rather than imposed. Second, part of the model can be used to explain the international variance in total factor productivity (TFP) growth. Following the theoretical framework of Corrado et al., 2009, Benhabib and Spiegel's model specifications from 1994 are expanded by intangibles. The starting point for the estimation is then an augmented Cobb-Douglas production function. Assuming constant returns to scale, the Cobb-Douglas production function is first rewritten in intensive form. Second, differences in natural logarithms are taken and the TFP term is estimated. This provides the following baseline for the econometric findings to be displayed at a later point in this contribution:

$$
\begin{aligned}
\left(\ln q_{i, t}-\ln q_{i, t-1}\right)= & c+g H_{i, t}+m H_{i, t} \frac{\left(q_{\max , t}-q_{i, t}\right)}{q_{i, t}}+n\left(1-u r_{i, t}\right) \\
& +p \sum_{j=1}^{k} X_{j, i, t}+y d_{i, t}+\alpha\left(\ln k_{i, t}-\ln k_{i, t-1}\right) \\
& +\beta\left(\ln r_{i, t}-\ln r_{i, t-1}\right)+u_{i, t}
\end{aligned}
$$

where labor productivity growth $\left(\ln q_{i, t}-\ln q_{i, t-1}\right)$ [gross value added for the nonfarm business sectors, expanded by the investment flows of business intangible capital in country $i$ and period $t$ ] can be essentially decomposed into a TFP term and two capital terms: tangible and intangible capital. TFP is represented by a constant term $c$, which represents exogenous technological progress. The level of human capital $\left(H_{i, t}\right)$ reflects the capacity of a country to innovate domestically. The term $H_{i, t} \frac{\left(q_{\text {max }, t}-q_{i, t}\right)}{q_{i, t}}$ proxies a catch-up process. The term $\left(1-u r_{i, t}\right)$ takes into account the business cycle effect. The term $p \sum_{j=1}^{k} X_{j, i, t}$ is the sum of $k$ extra policy variables which could possibly explain TFP growth. This includes public intangibles, e.g. formal and informal institutions such as the rule of law and trust. They are of central importance for growth. $y d_{i, t}$ are year dummies to control among others for 
the economic downturns in 2001 and 2008. Next comes the term for tangible capital services growth $\left(\ln k_{i, t}-\ln k_{i, t-1}\right)$. Followed by the term intangible capital services growth $\left(\ln r_{i, t}-\ln r_{i, t-1}\right)$ and the error term. In Sect. 5 we will elaborate upon the $\beta$-coefficient for intangibles capital services growth later within this contribution.

\section{Labor Productivity Growth, 1950-2006}

This section briefly describes the trends in labor productivity growth in the EU and the US from 1950 to 2006. Table 1 from Van Ark et al. (2008), depicts, inter alia, the average annual growth rates of GDP per hour worked in the EU-15 and the US from 1950 to 2006. The empirical evidence demonstrates that the labor productivity growth in the EU from 1950 to 1973, at 5.3\%, was twice as high as that in the US, at $2.5 \%$. The same pattern-although with lower numbers-holds for the period 1973-1995, with values of $2.4 \%$ for the EU-15 and $1.2 \%$ for the US. The literature clearly attributes the labor productivity growth increase in the EU vis-à-vis the US to a catching-up process. This process is built on a strong skill base instilled in upper secondary education and a production process based upon imitation. It is interesting to note that the pattern changes when analyzing the period 1995-2006, with US labor productivity growth increasing to $2.3 \%$, compared to $1.5 \%$ in the EU-15.

In analyzing the underlying contributions to labor productivity growth in Table 4 from their article, Van Ark et al. (2008) find that this decline in labor productivity growth in the EU is largely due to a scant contribution from the knowledge economy. A further sectoral decomposition by the authors demonstrates a pronounced decline in TFP growth in the market economy of the EU-15 vis-à-vis the US, particularly in market services. They link the productivity gap in EU market services to deficiencies in ICT and complementary investment in intangible capital as well as rigidities in the EU single market concerning product, labor and services markets.

Similar results in line with this overall argument are presented by a group of economists working with Sapir and Aghion et al., who stress the importance of public intangibles, namely the quantity and quality of higher education for explaining the gap in labor productivity growth (Aghion, 2008; Aghion \& Howitt, 2006; Aghion et al., 2007, 2008, 2010; Sapir et al., 2004). Brynjolfsson et al. (2019) stress investment in ICT and AI and lagged complementary intangible capital investments.

\section{The Productivity Puzzle, 2007-2015}

This brings us directly to the period starting from the Great Recession of 2007 and running up to 2015. Table 1 in Van Ark et al. (2018) illustrates a pronounced decline in labor productivity growth since the start of the Great Recession in 2008. Labor productivity growth rates dropped by half in the euro area (EA) from $1.4 \%$ to $0.6 \%$ and in the US from $2.5 \%$ to $1.3 \%$. As pointed out by Oulton (2018), this decline is 
exceptional in its magnitude and not just a continuation of past historical trends, as suggested by the American economic historians Gordon (2018) and Cowen (2011). But what triggered this stark decline in labor productivity growth?

Two channels have been identified in this field of research. First, the decline in labor productivity growth has been linked to a pronounced fall in total factor productivity growth. The long-term evidence produced by Bergeaud et al. (2016) and illustrated with time series findings on labor productivity growth and total factor productivity from 1890 to 2010 support such an assertion.

Second, the decline in labor productivity growth has been attributed to a drop in investment. Such claims are supported by analyses of investments in tangible capital, which have significantly declined over the period 2008-2013. The decline in tangible investment across EU economies is displayed in Fig. 1.1 as illustrated in the work by Roth (2020b). In particular, one detects the most pronounced decline in tangible capital investment in the periphery countries of the EA that implemented intensive austerity measures.

This decline in labor productivity growth and investment has puzzled many scholars for several reasons (Oulton, 2018; Remes et al., 2018; Van Ark \& Jäger, 2017). In the first instance, the decline was puzzling, given that real interest rates were close to or below zero (Teulings \& Baldwin, 2014; Summers, 2015; Haskel \& Westlake, 2018a).

Secondly, the decline was puzzling as it occurred in the midst of ongoing revolutions in ICT and AI (OECD, 2015). As pointed out by Nakamura (2019), the intensity of technological innovations since the beginning of the 1990s points to a "dramatically dynamic economy!" As can be discerned from Fig. 5.4 in Haskel and Westlake (2018a, p. 95), frontier firms actually saw a huge increase in their labor productivity growth. Furthermore, the available empirical evidence points to the increasing importance of intangibles among the S\&P 500 companies and notes the fact that the ten leading firms are almost entirely based on intangibles (Ross, 2020). They all give evidence in support of Nakamura's claim from 2019.

Several scholars, such as Lawrence Summers, identified a lack of aggregate demand as the main culprit behind declining labor productivity growth and investment (Draghi, 2014; Krugman, 2014; Summers, 2014, 2015). Applying their recommendations for stimulating aggregate demand to the EA implied two sets of strategies. First, on the condition that member states would adopt a structural reform agenda aimed at laying the basis for pro-growth support, the European Central Bank committed to implement a quantitative easing (QE) program. Secondly, the European Commission undertook to initiate an EU-wide European Investment Plan (Fichtner et al., 2014). However, a fiscal stimulus package proposed on behalf of the core economies, such as Germany, and favored by some prominent economists such as De Grauwe (2015) and Fratzscher (2014), was never launched.

Nevertheless, the policies initiated at the EU level have already been successful in stimulating demand support. They have thereby succeeded in initiating an economic recovery since 2014 and initiating investment in the EA, as shown in Fig. 1.1. Triggering aggregate demand support, however, is only the first step towards solving the productivity puzzle. Another essential step is linked to the incorporation of intangible capital investments into the asset boundary of the national accounts. 

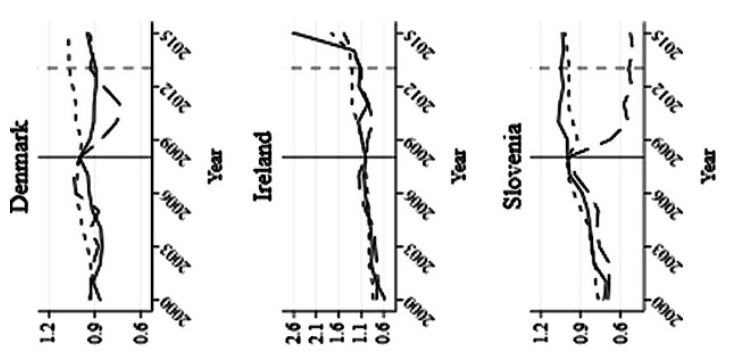

$\stackrel{m}{*} \frac{m}{8}$
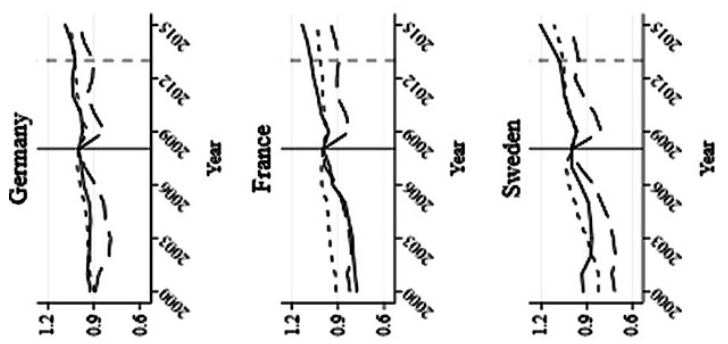

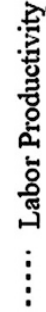

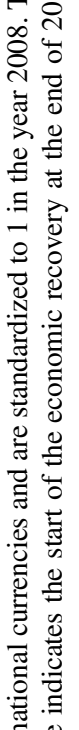
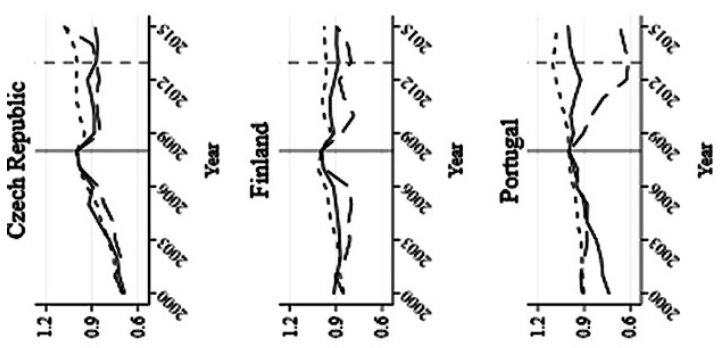

능

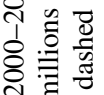

ํ. 를

니 $\sum_{0,0}^{0}$

टే ญ

की

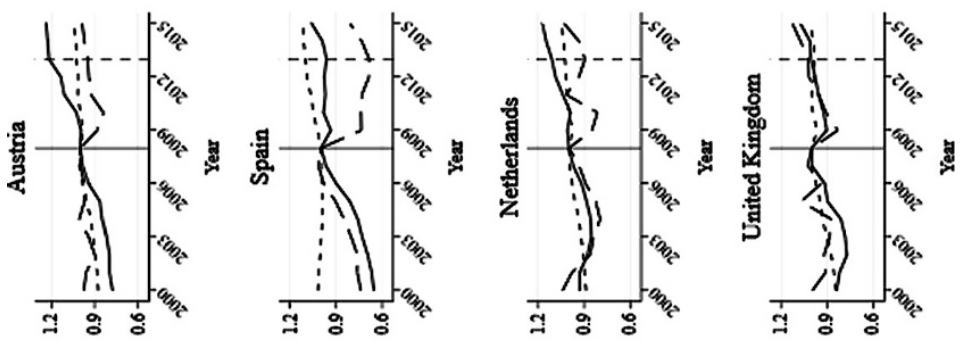

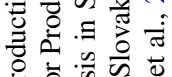

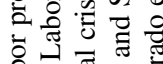

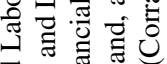

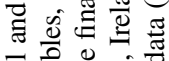

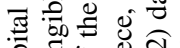

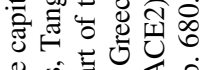

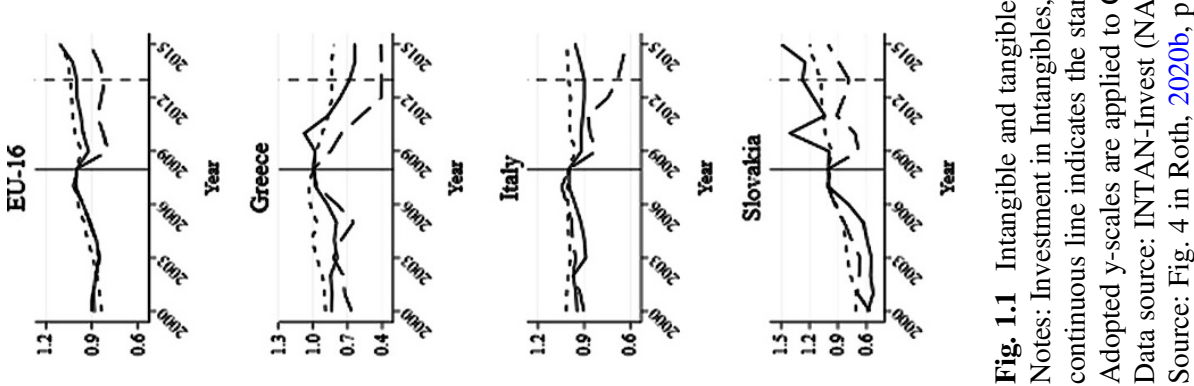




\section{Intangible Capital and the Productivity Puzzle}

But which investments in intangible capital should be incorporated into the asset boundary of national accounts? In their seminal paper published in 2005 and as shown in Table 1.1, Corrado, Hulten, and Sichel (CHS) categorize three dimensions of intangible assets (Corrado et al., 2005).

First, computerized information, which CHS define as "knowledge embedded in computer programs and computerized databases." Second, innovative property, which CHS define as "scientific knowledge embedded in patents, licenses and general know-how". Third, economic competencies, which CHS define as "the value of brand names and other knowledge embedded in firm-specific human and structural resources."

To what extent are these assets relevant for stimulating labor productivity growth? Let us consider two examples drawn from a chain of arguments developed by Brynjolfsson and Hitt (2000) and Brynjolfsson et al. (2002) over the last two decades. He and his team find that for every euro invested in software, a firm needs to spend an additional 10 euros in developing economic competencies if they want to reap the full potential of labor productivity growth. This includes the retraining of staff to use the software effectively, along with the necessary restructuring of organizational procedures. Similar results have been found for investments in AI.

And what economic contributions can be expected once these intangibles are incorporated into the asset boundary of national accounts? Table 1.2, taken from the

Table 1.1 Overview of business intangible assets employed in CHS (2005)

\begin{tabular}{|c|c|c|c|}
\hline $\begin{array}{l}\text { Category of } \\
\text { intangible } \\
\text { assets }\end{array}$ & Definition by CHS (2005) & $\begin{array}{l}\text { Business intangible } \\
\text { item }\end{array}$ & $\begin{array}{l}\text { Included } \\
\text { in NA }\end{array}$ \\
\hline \multirow{2}{*}{$\begin{array}{l}\text { Computerized } \\
\text { information }\end{array}$} & \multirow{2}{*}{$\begin{array}{l}\text { "Knowledge embedded in computer } \\
\text { programs and computerized databases" } \\
\text { (p.23) }\end{array}$} & Computer software & Yes \\
\hline & & Computerized database & Yes \\
\hline \multirow[t]{4}{*}{$\begin{array}{l}\text { Innovative } \\
\text { property }\end{array}$} & \multirow{4}{*}{$\begin{array}{l}\text { "Not only the scientific knowledge } \\
\text { embedded in patents, licenses and gen- } \\
\text { eral know-how (not patented) but also } \\
\text { the innovative and artistic content in } \\
\text { commercial copyrights, licenses and } \\
\text { designs" (p.26) }\end{array}$} & $\begin{array}{l}\text { Science and engineer- } \\
\text { ing R\&D }\end{array}$ & Yes \\
\hline & & Mineral exploration & Yes \\
\hline & & $\begin{array}{l}\text { Copyright and license } \\
\text { costs }\end{array}$ & Yes \\
\hline & & $\begin{array}{l}\text { Other product develop- } \\
\text { ment, design, and } \\
\text { research expenses }\end{array}$ & $\begin{array}{l}\text { No (new } \\
\text { intangible) }\end{array}$ \\
\hline \multirow[t]{3}{*}{$\begin{array}{l}\text { Economic } \\
\text { competencies }\end{array}$} & \multirow{3}{*}{$\begin{array}{l}\text { "The value of brand names and other } \\
\text { knowledge embedded in firm-specific } \\
\text { human and structural resources" (p.28) }\end{array}$} & Brand equity & \begin{tabular}{|l|} 
No (new \\
intangible)
\end{tabular} \\
\hline & & $\begin{array}{l}\text { Firm-specific human } \\
\text { capital }\end{array}$ & $\begin{array}{l}\text { No (new } \\
\text { intangible) }\end{array}$ \\
\hline & & $\begin{array}{l}\text { Organizational } \\
\text { structure }\end{array}$ & $\begin{array}{l}\text { No (new } \\
\text { intangible) }\end{array}$ \\
\hline
\end{tabular}

Note: $\mathrm{NA}=$ national account.

Source: Own adaption of CHS (2005) as published in Table 1 in Roth, 2019, p. 6. 


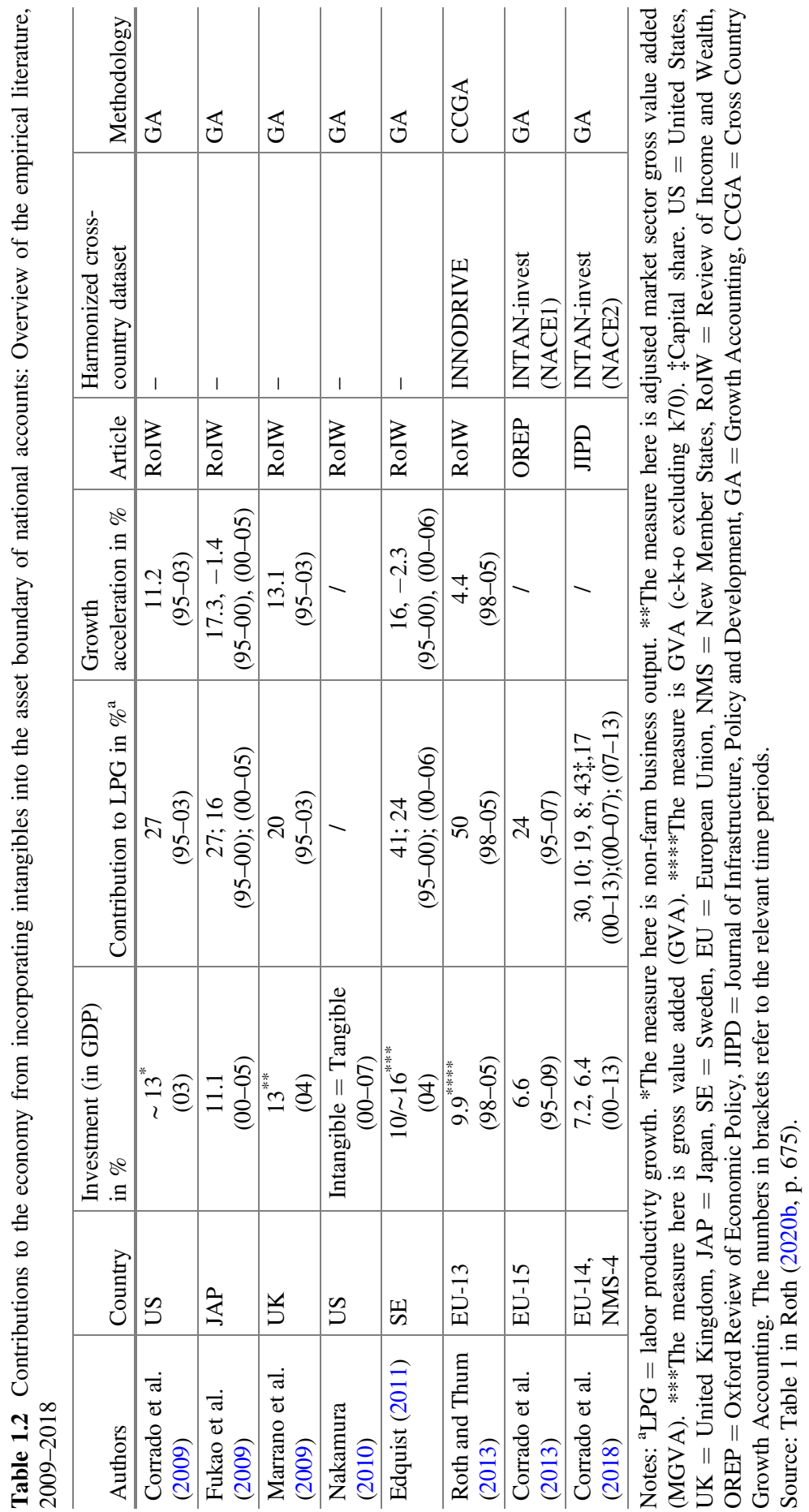


work by Roth (2020b), summarizes three sets of main findings as reported in the literature.

First, investment as a percentage of GDP increases significantly and approaches levels comparable to those of tangible capital once intangibles are incorporated. Second, intangibles constitute a significant contribution to labor productivity growth. For example, the work by Roth and Thum (2013) shows that growth in intangible capital services is able to explain $50 \%$ of the international variance in labor productivity growth in the EU. It becomes, in fact, its dominant driver. Third, the rate of labor productivity growth accelerates. As reported by Edquist (2011), e.g., once accounting for intangibles, labor productivity growth accelerates by $16 \%$ in Sweden.

What are the implications of these findings for the productivity puzzle? Four points can be elaborated. First, the "puzzling" decline in investment is largely due to a mismeasurement in most advanced economies of the actual ongoing investment rates by firms. Contemporary national accounting classifications have not yet been fully revised to account for the ongoing transition towards the knowledge economy of the twenty-first century. Although selective elements of intangibles have already been accounted for, such as software and scientific R\&D, investments in economic competencies, such as firm-specific human and organizational capital, are still excluded.

Figure 1.2, taken from the work by Roth (2020b, p. 680), illustrates that once intangibles are included in the national accounts, overall business investments in an EU-16 country sample are almost twice as high and represent $25 \%$ of the total sum. Moreover, it is interesting to observe that in seven out of the 16 countries surveyed, business investments in intangible capital are already larger than those in tangible capital.

Figure 1.1 also shows that despite a steady decline in tangible investments, particularly in the aftermath of the financial crisis, investments in intangible capital have swiftly recovered and are on a steadily upward trend. These results are consistent with the latest evidence from the INNODRIVE follow-up INTAN-Invest dataset, referenced in a speech given early in 2020 by Jonathan Haskel, British economist and Member of the Monetary Policy Committee at the Bank of England. This evidence illustrates a steady decline in tangible capital and a solid increase in intangible capital in the post-financial crisis era in advanced economies. The above findings demonstrate that the use of tangible investment flows as the sole basis of analysis leads to erroneous empirics and ultimately to the design of misguided policy measures.

Second, incorporating intangibles into the asset boundary of national accounts leads to an increase in labor productivity growth. This has already been shown by Edquist (2011) for the case of Sweden. His results differ from claims published by Haskel and Westlake (2018a) and Syverson (2017). The results by Roth (2020b) from the GLOBALINTO project in 2020 support Edquist's (2011) findings. Other analyses of economic recovery show that labor productivity growth has accelerated by $0.4 \%$ points (or $22 \%$ ), from $1.8 \%$ to $2.2 \%$. In this context, Nakamura (2019) even suggests that the mismeasurement of labor productivity growth will most likely give an annual growth rate of $2 \%$. 


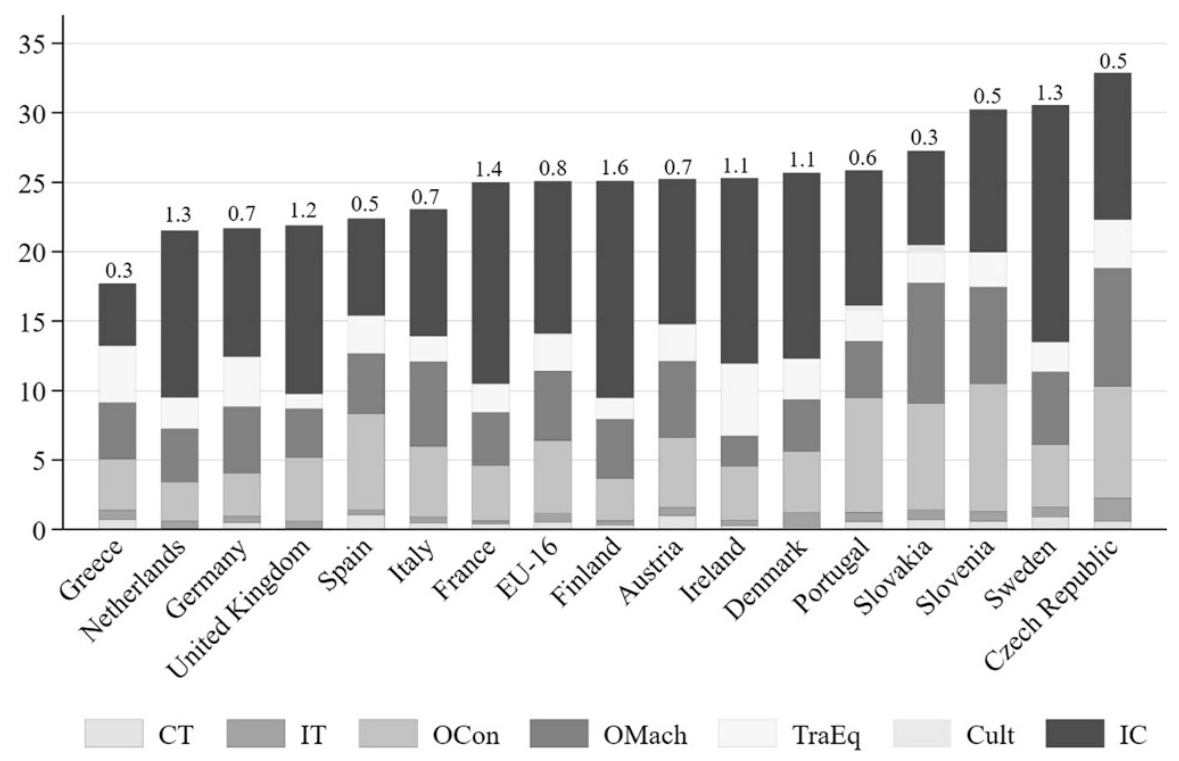

Fig. 1.2 Business tangible and intangible capital investments (as a percentage of GVA), EU16, 2000-2015

Notes: CT = communications technology; IT = information technology; OCon $=$ total nonresidential capital investment; OMach $=$ other machinery and equipment; $\operatorname{TraEq}=$ transport equipment; Cult $=$ cultivated assets; IC $=$ intangible capital. Residential Structure has been excluded. Values on top of the bars depict the intangible/tangible capital investment ratio.

Data sources: INTAN-Invest (NACE2) data (Corrado et al., 2018) and EUKLEMS data (Jäger, 2017).

Source: Fig. 3 in Roth, 2020b, p. 680.

Third, several prominent contributions have highlighted the role of a decline in TFP in relation to the level of business investments in intangibles. Van Ark (2016), Van Ark and O'Mahony (2016), Van Ark and Jäger (2017), as well as Bounfour and Miyagawa (2015) attribute the decline in labor productivity and TFP growth primarily to a slower diffusion of technology and innovation, which is due to low growth rates of investments in ICT and complementary intangibles. Haskel and Westlake (2018b) also highlight a reduction in the spill-over effects of intangibles on TFP due to the widening gap of intangible investment between leader and laggard firms. Moreover, Brynjolfsson et al. (2019) argue that more investment in complementary intangibles is necessary to reap the full benefits of AI to labor productivity growth.

Fourth, as can be seen in Table 1.3 as taken from Roth (2020b), the econometric results point towards the importance of intangible capital services growth for labor productivity growth at the macro-level. The work by Roth from 2020 uses a crosscountry growth accounting estimation approach for an EU-16 country sample over the period 2000-2015. It is based on the intangible augmented model specification as 
Table 1.3 Intangibles and labor productivity growth, 2000-2015, PP-PCSE estimation

\begin{tabular}{|c|c|c|c|c|c|c|}
\hline Estimation method & $\begin{array}{l}\text { PP- } \\
\text { PCSE }\end{array}$ & $\begin{array}{l}\text { PP- } \\
\text { PCSE }\end{array}$ & $\begin{array}{l}\text { PP- } \\
\text { PCSE }\end{array}$ & $\begin{array}{l}\text { PP- } \\
\text { PCSE }\end{array}$ & $\begin{array}{l}\text { PP- } \\
\text { PCSE }\end{array}$ & 2SLS \\
\hline Time sample & $\begin{array}{l}2000- \\
2015\end{array}$ & $\begin{array}{l}2000- \\
2015\end{array}$ & $\begin{array}{l}2000- \\
2015\end{array}$ & $\begin{array}{l}2008- \\
2015\end{array}$ & $\begin{array}{l}2000- \\
2015\end{array}$ & $\begin{array}{l}2000- \\
2015\end{array}$ \\
\hline Equation & (1) & (2) & $(3)$ & $(4)$ & (5) & (6) \\
\hline \multirow{2}{*}{$\begin{array}{l}\text { Tangible services } \\
\text { growth }\end{array}$} & $0.31 * * *$ & $0.19 * *$ & $0.28 * * *$ & -0.13 & $0.18 * *$ & 0.58 \\
\hline & $(0.08)$ & $(0.08)$ & $(0.08)$ & $(0.15)$ & $(0.07)$ & $(0.42)$ \\
\hline \multirow{2}{*}{$\begin{array}{l}\text { Tangible services } \\
\text { growth* crisis }\end{array}$} & - & - & $-0.32 * *$ & - & - & - \\
\hline & & & $(0.13)$ & & & \\
\hline \multirow{2}{*}{$\begin{array}{l}\text { Tangible services } \\
\text { growth*recovery }\end{array}$} & - & - & - & 0.47 & - & - \\
\hline & & & & $(0.30)$ & & \\
\hline \multirow{2}{*}{$\begin{array}{l}\text { Intangible services } \\
\text { growth }\end{array}$} & - & $0.38 * * *$ & $0.48 * * *$ & $0.32 * * *$ & - & $0.50 * * *$ \\
\hline & & $(0.07)$ & $(0.09)$ & $(0.11)$ & & $(0.16)$ \\
\hline \multirow{2}{*}{$\begin{array}{l}\text { Intangible services } \\
\text { growth*crisis }\end{array}$} & - & - & $-0.28 * *$ & - & - & - \\
\hline & & & $(0.13)$ & & & \\
\hline \multirow{2}{*}{$\begin{array}{l}\text { Intangible services } \\
\text { growth*recovery }\end{array}$} & - & - & - & $0.42 *$ & - & - \\
\hline & & & & $(0.23)$ & & \\
\hline \multirow{2}{*}{$\begin{array}{l}\text { Innovative property } \\
\text { services growth }\end{array}$} & - & - & - & - & $0.37 * * *$ & - \\
\hline & & & & & $(0.07)$ & \\
\hline \multirow{2}{*}{$\begin{array}{l}\text { Computerized informa- } \\
\text { tion services growth }\end{array}$} & - & - & - & - & -0.01 & - \\
\hline & & & & & $(0.04)$ & \\
\hline \multirow{2}{*}{$\begin{array}{l}\text { Economic competencies } \\
\text { services growth }\end{array}$} & - & - & - & - & 0.02 & - \\
\hline & & & & & $(0.06)$ & \\
\hline \multirow{2}{*}{$\begin{array}{l}\text { Upper secondary } \\
\text { education } 15+\end{array}$} & $0.07 * * *$ & $0.05 * * *$ & $0.05 * * *$ & 0.02 & $0.06 * * *$ & $0.07 * * *$ \\
\hline & $(0.02)$ & $(0.01)$ & $(0.01)$ & $(0.02)$ & $(0.01)$ & $(0.02)$ \\
\hline \multirow[t]{2}{*}{ Catch-up } & $-0.02 * *$ & $-0.02 * * *$ & $-0.02 * * *$ & -0.01 & $-0.02 * *$ & $-0.02 *$ \\
\hline & $(0.01)$ & $(0.01)$ & $(0.01)$ & $(0.01)$ & $(0.01)$ & $(0.01)$ \\
\hline \multirow[t]{2}{*}{ Business cycle } & $-0.11 *$ & $-0.12 *$ & $-0.13 * *$ & $-0.13^{*}$ & $-0.12 *$ & $-0.11 * *$ \\
\hline & $(0.06)$ & $(0.06)$ & $(0.06)$ & $(0.07)$ & $(0.06)$ & $(0.05)$ \\
\hline R-squared & 0.40 & 0.50 & 0.54 & 0.63 & 0.54 & 0.46 \\
\hline Observations & 256 & 256 & 256 & 128 & 256 & 208 \\
\hline Number of countries & 16 & 16 & 16 & 16 & 16 & 16 \\
\hline
\end{tabular}

Notes: PP-PCSE = Pooled Panel - Panel-Corrected Standard Error. In regression (1), tangible services growth, labor productivity growth, and the catch-up term exclude software, R\&D, and entertainment, artistic and literary originals, and mineral exploration. In regressions, (2-6) labor productivity growth and the catch-up term are expanded with intangible capital. Tangible capital excludes residential capital. Labor productivity growth was calculated based on the GVA of the non-farm business sectors $\mathrm{b}-\mathrm{n}+\mathrm{r}-\mathrm{s}$ (excluding real estate activities). ***p $<0.01$, ** $\mathrm{p}<0.05$, $* \mathrm{p}<0.1$.

Source: Table 2 in Roth, 2020b, p. 682.

introduced in the beginning of this contribution. It provides evidence that growth in intangible capital services can explain the largest share of labor productivity growth-up to $66 \%$. This is demonstrated by the size of the beta coefficient of 0.38. Equally significant, but less pronounced results are found at the meso and micro-levels (Niebel et al., 2017; Marrocu et al., 2011). 


\section{An Outlook on the COVID-19 Crisis and Labor Productivity Growth}

How will the present COVID-19 crisis affect labor productivity growth? In order to answer this question, we should distinguish between a short-term and a medium- to long-term perspective.

To understand the short-term impact, it helps to examine the pattern that emerged in the aftermath of the 2008 financial crisis. Table 6, taken from Mas (2012), presents evidence from the EU and the US in the period 2007-2010, which shows that whereas the US saw an actual increase in labor productivity growth from $1.93 \%$ to $2.02 \%$, the EU-15 experienced a pronounced decline in labor productivity growth from $1.41 \%$ to $0.07 \%$. This difference can be attributed to differences in labor market arrangements between the two economies. Whereas EU welfare states have intensively utilized short-term working schemes to dampen the threat of large layoffs in the aftermath of the financial crisis, the US refrained from such policies.

And indeed, as can be observed in the data from the spring 2020 projections by DG ECFIN, labor productivity growth in the EA will decline by $3.2 \%$ points, with a peak in Germany of 5.6\% points (European Commission, 2020a). Conversely, the decline in US labor productivity growth will be marginal, estimated at only $0.2 \%$ points. Much like the experience following the financial crisis in 2009, the shortterm working schemes adopted to dampen the threat of large layoffs will lead to a pronounced decline in labor productivity growth in the euro area and in Germany vis-á-vis the US. But how large is the economic impact caused by the COVID-19 pandemic from a historical perspective?

Recent evidence generated from empirical time series performed by Bergeaud et al. (2020) over the period 1875-2025 shows that, although the impact on GDP growth is more pronounced than that from the financial crisis in 2008, it is only a fraction of the decline suffered during the Great Depression in 1929. Furthermore, there will be a swift recovery in 2021 beyond the previous level. Also, a similar decline in investment in 2020 due to the COVID-19 crisis, with a strong recovery in 2021, is projected by ECFIN (European Commission, 2020a). Whether this holds also for intangible capital investment remains an open question. We hope to arrive at an answer by means of a customized COVID-19 survey to be administered by the GLOBALINTO project (GLOBALINTO, 2020) on business intangible capital investment in seven EU countries.

To understand the mid- and long-term impact, we must first analyze the policy measures adopted to address the COVID-19 crisis. In response to the pandemic, historically large stimulus packages of up to 200 billion euro were agreed at the member state level among selective core countries of the EA (Greive, 2020). At the federal level of the EU, the agreed overall fiscal capacity is 750 billion euro (European Commission, 2020b). These fiscal policies are flanked by the ECB's Pandemic Emergency Purchase Programme (PEPP), with a total volume of 1350 billion euro. The novelty of PEPP is the role being assumed by the ECB to act as lender of last resort in the government bond market, with no restrictions placed on 
single-country purchases (Schnabel, 2020). For the European Commission to borrow 750 billion euro in its capacity as a multinational actor within its multiannual financial framework is equally historic. This is most likely a significant step forward towards establishing a stronger fiscal union. As pointed out in my latest work, given the large public support shown for the euro during its first two decades, it is likely that the presidents of both the ECB and the European Commission enjoy the necessary political legitimacy to enact these decisive measures (Roth, 2020c).

But will these investment plans help to stimulate a recovery in the EA? As we learned from the arguments presented above, these stimuli will surely help the euro area to recover in the short-term, especially given that it is a three-fold program this time round: fiscal stimuli at the member state and EU levels, paired with monetary stimuli.

In a medium- to long-term perspective, two issues are relevant for a full recovery of labor productivity growth. First, the current push for digitization needs to be backed by investments from the recovery packages into digitization and the necessary complementary (business and public) intangible capital. If the funds are used in such a manner, we can expect to see labor productivity growth accelerate in the postCOVID-19 era. Second, the ongoing investments in ICT and in intangibles must be flanked by pro-growth supply-side reforms within the labor, product, and services markets in the larger EA economies, such as Italy. This should achieve the necessary convergence in unit labor costs vis-á-vis Germany.

A post-COVID-19-scenario will likely lead to a pronounced increase in labor productivity growth. This depends, however, on whether the current push for digitization will be backed by actual investments in digitization and the necessary complementary investments in (business and public) intangible capital.

\section{Conclusion}

We now come to the main conclusion of this contribution, which has attempted to critically assess the productivity puzzle and give an outlook on the COVID-19 crisis . It offers two main conclusions.

First, it posits that a large fraction of the productivity puzzle can be solved by incorporating intangible capital into the asset boundary of the national accounts. Thus, the productivity puzzle is largely explained as a consequence of fundamental structural changes that are underway, transforming industrial economies into knowledge economies. And it is precisely this radical transformation that yet needs to be statistically validated by the national accounts.

Secondly, the contribution foresees a post-COVID-19 scenario that will likely lead to a pronounced increase in labor productivity growth. This depends, however, on whether the current push for digitization will be backed by actual investments in digitization and the necessary complementary investments in (business and public) intangible capital. 


\section{References}

Aghion, P. (2008). Higher education and innovation. Perspektiven der Wirtschaftspolitik, 9, 28-45.

Aghion, P., \& Howitt, P. (2006). Joseph Schumpeter lecture appropriate growth policy: A unifying framework. Journal of the European Economic Association, 4, 269-314.

Aghion, P., Dewatripont, M., Hoxby, C., Mas-Colell, A., \& Sapir, A. (2007). Why reform Europe's universities?. Bruegel Policy Brief 4. Brussels, Bruegel.

Aghion, P., Dewatripont, M., Hoxby, C., Mas-Colell, A., \& Sapir, A. (2008). Higher aspirations: An agenda for reforming European universities. Bruegel Blueprint Series 5. Brussels, Bruegel.

Aghion, P., Dewatripont, M., Hoxby, C., Mas-Colell, A., \& Sapir, A. (2010). The governance and performance of universities: Evidence from Europe and the US. Economic Policy, 1, 7-59.

Benhabib, J., \& Spiegel, M. M. (1994). The role of human capital in Economic DevelopmentEvidence from aggregate cross-country data. Journal of Monetary Economics, 34, 143-173.

Bergeaud, A., Cette, G., \& Lecat, R. (2016). Productivity trends in advanced countries between 1890 and 2012. Review of Income and Wealth, 62, 420-444.

Bergeaud, A., Cette, G., \& Lecat, R. (2020). Current and past recessions: A long-term perspective. ECO note pad Banque de France 159, 27 April.

Bounfour, A., \& Miyagawa, T. (2015). Intangibles, market failure and innovation growth (pp. 1-10). Springer Verlag.

Brynjolfsson, E., \& Hitt, L. M. (2000). Beyond computation: Information technology, organizational transformation and business performance. Journal of Economic Perspectives, 14, 23-48.

Brynjolfsson, E., Hitt, L. M., \& Yang, S. (2002). Intangible assets: Computers and organizational capital. Brookings Papers on Economic Activity, 1, 137-198.

Brynjolfsson, E., Rock, D. and Syverson, C. (2019). Artificial intelligence and the modern productivity paradox: A clash of expectations and statistics. In: A. Agrawal, J. Gans, and A. Goldfarb (eds.) (2019): The economics of artificial intelligence: An agenda, University of Chicago Press, pp. 23-57.

Corrado, C., Hulten, C., \& Sichel, D. (2005). Measuring capital and technology: An expanded framework. In C. Corrado, J. Haltiwanger, \& D. Sichel (Eds.), Measuring capital in the new economy (pp. 11-46). University of Chicago Press.

Corrado, C., Hulten, C., \& Sichel, D. (2009). Intangible capital and U.S. Economic growth. Review of Income and Wealth, 55, 661-685.

Corrado, C., Haskel, J., Jona-Lasinio, C., \& Iommi, M. (2013). Innovation and intangible investment in Europe, Japan, and the United States. Oxford Review of Economic Policy, 29, 261-286.

Corrado, C., Haskel, J., Jona-Lasinio, C., \& Iommi, M. (2018). Intangible investment in the EU and US before and since the great recession and its contribution to productivity growth. Journal of Infrastructure, Policy and Development, 2, 11-36.

Cowen, T. (2011). The great stagnation: How America ate all the low-hanging fruit of modern history, got sick, and will (eventually) feel better. Dutton.

De Grauwe, P. (2015). Secular stagnation in the eurozone. VoxEU. 30 January.

Draghi, M. (2014). Unemployment in the Euro Area, Speech at the Annual Central Bank Symposium in Jackson Hole, 22 August, Wyoming.

Edquist, H. (2011). Can Investment in Intangibles Explain the Swedish productivity boom in the 1990s? The Review of Income and Wealth, 57, 658-682.

European Commission. (2020a). European Economic Forecast, European Economy Institutional Paper 125. European Union.

European Commission. (2020b). Communication from the Commission to the European Parliament, the European Council, the Council, the European Economic and Social Committee and the Committee of the regions: The EU budget powering the recovery plan for Europe COM/2020/442 final, Brussels.

Fichtner, F., Fratzscher, M., \& Gornig, M. (2014). Eine Investitionsagenda für Europa. DIW Wochenbericht, 27, 631-635. 
Fratzscher, M. (2014). Die Deutschland-Illusion: Warum wir unsere Wirtschaft überschätzen und Europa brauchen. Carl Hanser Verlag.

Fukao, K., Miyagawa, T., Mukai, K., Shinoda, Y., \& Tonogi, K. (2009). Intangible investment in Japan: Measurement and contribution to economic growth. Review of Income and Wealth, 55, 717-736.

GLOBALINTO (2020): Capturing the value of intangible assets in micro data to promote the EU's growth and competitiveness. https://globalinto.eu/.

Gordon, R. J. (2018). Declining American growth despite ongoing innovation. Explorations in Economic History, 69, 1-12.

Greive, M. (2020). Bund macht fast 220 Milliarden Euro neue Schulden. Handelsblatt. 15 June.

Haskel, J. \& Westlake, S. (2018a). Capitalism without capital. Princeton University Press.

Haskel, J. \& Westlake, S. (2018b). Productivity and secular stagnation in the intangible economy. Vox.EU. 31 May.

Haskel, J. (2020). Monetary policy in the intangible economy. Bank of England Speech given at the University of Nottingham. 11 February.

Heil, M. (2018). Finance and productivity: A literature review. Journal of Economic Surveys, 32, $1355-1383$.

INNODRIVE. (2011). INNODRIVE intangibles database. (https://cordis.europa.eu/project/id/ 214576/reporting/de).

Jäger, K. (2017). EU KLEMS growth and productivity accounts 2017 release - description of methodology and general notes. Available at: http://www.euklems.net/TCB/2017/ Metholology_EU\%20KLEMS_2017.pdf.

Krugman, P. (1994). Competitiveness: A dangerous obsession. Foreign Affairs, 73, $28-44$.

Krugman, P. (2014). Depression are different. In R. M. Solow \& J. Murray (Eds.), Economics of the curious (pp. 7-18). Palgrave Macmillan.

Marrano, M., Haskel, J., \& Wallis, G. (2009). What happened to the knowledge economy? ICT, intangible investment, and Britain's productivity record revisited. Review of Income and Wealth, 55, 686-716.

Marrocu, E., Raffaele, P., \& Pontis, M. (2011). Intangible capital and firms' productivity. Industrial and Corporate Change, 21, 377-402.

Mas, M. (2012). Productivity in the advanced countries: From expansion to crisis. In M. Mas \& R. Stehrer (Eds.), Industrial productivity in Europe (pp. 11-34). Edward Elgar.

Nakamura, L. (2010). Intangible assets and national income accounting. Review of Income and Wealth, 56, 135-155.

Nakamura, L. (2019). Economic growth--too slow or too fast? Measuring the value of intangibles and AI, presentation at the 15th world conference on intellectual Capital for Communities on the 11th and 12th July. UNESCO.

Niebel, T., O'Mahony, M., \& Saam, M. (2017). The contribution of intangible assets to sectoral productivity growth in the EU. The Review of Income and Wealth, 63, 49-67.

OECD (2015). The future of productivity. OECD.

Oulton, N. (2018). Productivity and the great recession. Intereconomics, 53, 63-68.

Posen, A. S. \& Zettelmeyer, J. (2019). Facing up to low productivity growth: Introduction. In A. S. Posen \& J. Zettelmeyer (Eds.), Facing up to low productivity growth (pp. 1-11). Columbia University Press.

Remes, J., Mischke, J., \& Krishnan, M. (2018). Solving the productivity puzzle: The role of demand and the promise of digitization. International productivity Monitor, 35, 28-51.

Ross, M. (2020). Intangible assets: A hidden but crucial driver of company value. Downloadable at: https://www.visualcapitalist.com/intangible-assets-driver-company-value/.

Roth, F. (2019). Intangible capital and labour productivity growth: A literature review. Hamburg discussion papers in international economics 4. Hamburg, Germany.

Roth, F. (2020a). The productivity puzzle - A critical assessment, Habilitation Colloquium Lecture delivered before the Habilitation Committee of the Faculty of Business, Economics and Social Sciences at the University of Hamburg on June 29. 
Roth, F. (2020b). Revisiting intangible capital and labour productivity growth, 2000-2015: Accounting for the crisis and economic recovery in the EU. Journal of Intellectual Capital, 21, 671-690.

Roth, F. (2020c). Economic recovery strengthens public support for the euro, JCMS-blog, 9. January.

Roth, F. (2021). Das Produktivitätspuzzle - Eine kritische Bewertung. In: T. Straubhaar (Hg.): Datenwirtschaft: was ist neu und anders?, (pp. 61-82). Hamburg University Press.

Roth, F., \& Thum, A.-E. (2013). Intangible capital and labour productivity growth. Review of Income and Wealth, 59, 486-508.

Sapir, A., Aghion, P., Bertola, G., Hellwig, M., Pisani-Ferry, J., Rosati, D., Vinals, J., \& Wallace, H. (2004). An agenda for growing Europe. Oxford University Press.

Schnabel, I. (2020). The ECB's policy in the COVID-19 crisis - A medium-term perspective, European Central Bank speech, 10 June 2020, Frankfurt am Main. ECB.

Summers, L. (2014). Reflections on the "new secular stagnation hypothesis". VOXEU. 15 August.

Summers, L. (2015). Demand side secular stagnation. American Economic Review, 105, 60-65.

Syverson, C. (2017). Challenges to mismeasurement explanations for the US productivity slowdown. Journal of Economic Perspectives, 31, 165-186.

Teulings, C., \& Baldwin, R. (2014). Secular stagnation: Facts, causes and cures. VOXEU. 15 August.

Van Ark, B., O'Mahony, M., \& Timmer, M. (2008). The productivity gap between Europe and the United States: Trends and causes. Journal of Economic Perspectives, 22, 25-44.

Van Ark, B. (2016). Europe's productivity slowdown revisited: A comparative perspective to the United States. In P. Askenazy, L. Bellmann, A. Bryson, \& E. Moreno Galbis (Eds.), Productivity puzzles across Europe (pp. 26-48). Oxford University Press.

Van Ark, B., \& O'Mahony, M. (2016). Productivity growth in Europe before and since the 2008/ 2009 economic and financial crisis. In D. Jorgensen, K. Fukao, \& M. P. Timmer (Eds.), The world economy: Growth stagnation (pp. 111-152). Cambridge University Press.

Van Ark, B., \& Jäger, K. (2017). Recent trends in Europe's output and productivity growth performance at the sector level, 2002-2015. International Productivity Monitor, 33, 8-23.

Van Ark, B., de Vries, K., \& Jäger, K. (2018). Is Europe‘s productivity glass half full or half empty? Intereconomics, 53, 53-58.

Open Access This chapter is licensed under the terms of the Creative Commons AttributionNonCommercial-NoDerivatives 4.0 International License (http://creativecommons.org/licenses/bync-nd/4.0/), which permits any noncommercial use, sharing, distribution and reproduction in any medium or format, as long as you give appropriate credit to the original author(s) and the source, provide a link to the Creative Commons license and indicate if you modified the licensed material. You do not have permission under this license to share adapted material derived from this chapter or parts of it.

The images or other third party material in this chapter are included in the chapter's Creative Commons license, unless indicated otherwise in a credit line to the material. If material is not included in the chapter's Creative Commons license and your intended use is not permitted by statutory regulation or exceeds the permitted use, you will need to obtain permission directly from the copyright holder. 